\title{
Heroes as Predictors of Future Employees' Behaviour
}

\author{
Helena Šajgalíková \\ Faculty of Applied Languages \\ University of Economics \\ Bratislava, Slovakia \\ helena.sajgalikova@euba.sk
}

\author{
Lukáš Copuš* \\ Faculty of Management \\ Comenius University \\ Bratislava, Slovakia \\ lukas@copus.sk
}

\begin{abstract}
One of the HR personnel's roles is to identify the reasons for behaviour of their current and future employees. To identify their behavioural models is one of potential techniques. The paper deals with the findings of the research focused on identifying heroes and the values they represent in the group of adolescents in Slovak secondary schools. The findings show that the most represented category of heroes is a family member/relative followed by a publicly known person.
\end{abstract}

Keywords-Behavioural model; Generation Z; Hero; Human development; Human resources; Idol; Role model; Values

\section{INTRODUCTION AND THEORETICAL BACKGROUND}

In their strategies, global economies including the European ones strive for achieving sustainable growth. In addition to technologies, human resources play a crucial role in all of them. The Europe Strategy 2020 [1] focuses on enhancing employment and the relevant education levels as well as lowering poverty and social exclusion related to the economic situation of individuals. The plan is to reach that $75 \%$ of people aged 20-64 are employed. Another priority related to education aims at the rate of early school-leavers to drop below $10 \%$ and minimum $40 \%$ of people in their early 30 -ties to complete higher education.

All the documents of the kind [e.g. 1] present the goals as if the generation of potential employees was automatically prepared to fulfil the ambitious goals. This means that they do not question the feasibility of the ambition to achieve the goal.

In our research we look for the answers to the questions that help identify the values and preferences of those who are hot candidates for the labour market in question. To collect the meaningful responses we focus on the group of adolescents (secondary school students) who, on the one hand, represent the first larger group potentially entering the labour market, or, on the other hand, decide to continue in their studies, meeting thus the government's plan to increase the numbers of employees - graduates of higher education institutions.

The current situation with the lack of 'qualified' workforce (in its widest meaning) shows that to satisfy the needs of employers not only technical competences are needed, but also the personality of the employee plays the crucial role in their successful performance [2].

What are the values and preferences then that employees should exercise to fulfil the more demanding tasks for the employers? How can they be identified? Can they be modified in the early age? These are the questions that the employment policymakers, labour market as such, and managers must answer if they want to meet the strategic goals in the near and further future.

During the lifetime, everybody's development is multidimensional. It is not only the physical development, but cognitive and psychosocial one as well [3]. It is developmental psychology that tackles the above-mentioned aspects (evolved from the interest in child development, later on human development, currently dealing with lifespan development) [4].

In the frame of developmental psychology an individual's development (in the perspective of our survey, namely the development of adolescents) has been presented in various models. Piagett's 'stage theory' stems from the idea that the development of all humans is based on similar paths [5]. Vygotsky who claims that adults interfere in a child or adolescent's development in the critical phases (called zones of proximal development) represents another viewpoint [6]. Usually, these adults are their parents. In their recent study offering an overview of various surveys in developmental psychology, Kogan et al. confirm that the parents' influence on the children's development in particular areas, e.g. in the perspective of their success in future studies, is evident [7]. Of course, parents constitute only one group of people influencing children and adolescents. Shaffer et al. argue that the adults play different roles (a role of parent, teacher, nurse, psychologist) in which they influence children and adolescents and introduce practical recommendations that might be applied within the context of a particular role. However, they are not only adults that influence development of children and adolescents, but also their peers and friends [8].

As comes from the above-mentioned, children and adolescents are mostly influenced by those with whom they are in personal contact. Today's generation of children and adolescents labelled generation Z (generally, those born after the year 1995 [9], even though there is no consensus on the time covered [10]) is, at the same time, influenced by another force - by the Internet [11]. Unlimited amount of information including daily news on popular people (sportsmen, politicians, singers, actors, and the like) has resulted in the influence on the children and adolescents' development without any personal contact [12]. The influence of the well-known people on the personality development is not a new phenomenon and occurred in the past as well, however, the extent of the print did not reach its current degree then.

The impact exercised by the above-mentioned individuals or groups (parents, friends, popular persons, etc.) differs in some aspects. A popular actor/actress can unlikely give the 
child or adolescent personalised advice relevant for their life paths what can be, and usually is, given by a parent. From psychological perspective, children or adolescents can view such people as their heroes [13] (or, as other theorists term them, idols [14], examples [15], role models [16], or behavioural models [17]). The effect of heroes on children and adolescents' behaviour has been covered by a number of surveys from various perspectives [18].

One of the hero functions is an instructional one [19]. It stems from the assumption that the child or adolescent follows the behaviour of his/her hero if he/she considers it positively in comparison with his/her own behaviour. In such a case the child or adolescent feels that he/she is not as good as his/her hero, but he/she wants to become like the hero in question.

The identification of the heroes recognized by a child/adolescent helps draw a picture of his/her current and future direction [20] in relation to his/her personal or professional career [21]. In the group of secondary school students this perspective acquires specific importance because this is the time when they decide about their future professional career. Simply put, it can mean either further schooling at a higher education institution or direct placement on the labour market. Identification of heroes can be used as an indicator of their future behaviour when performing for an employer and can bring a new dimension to recruitment and selection processes of employment candidates. The same can be identified in the case of the adolescent's further studies, primarily in relation to his/her early dropout. So far only little attention has been paid to this aspect.

The identification of heroes is, however, just the initial information that needs interpretation in the wider context. Every category of heroes can be considered a proper behavioural model in one context, however, an absolutely inappropriate one in another. The criteria applied in behavioural models assessment allowing for considering models appropriate or inappropriate are ambiguous. As an example we can use the heroes of the sportsman/woman category. On the one hand, the adolescents admire in them the values such as success and ambitions that can have positive impact on their future professional behaviour based on such values. On the other hand, there are jobs that are based on other values, not those attributed to sportsmen. To understand the role of the hero in behaviour shaping, the value system that the hero represents must be identified [15, 17, 20, 22].

The objective of the survey is to identify the heroes recognized by Slovak secondary school students (future employees) as the representatives of the values attributed to them by the respondents. The findings can be utilized in recruitment and selection processes by human resources [23, $24]$ as well as lowering the rate of dropouts in higher education.

\section{RESEARCH AND METHODOLOGY}

The research was executed via questionnaires consisting of demographic questions related to age, gender, region, and 4 research questions (open as well as closed).

The categories of heroes included family members, various categories of publicly known persons, and literary and movie characters. The respondents could introduce a hero of their choice as well. The previous research identified the values represented by individual categories of heroes [21].

The values of heroes included: social influence; frankness; friendliness and outgoingness; diligence; stubbornness; generosity; honesty and fairness; modesty; success; creativity; ambitions and determination; responsibility; support of others; courage and fearlessness; beauty; wealth (money); talent; kindness; wisdom and intelligence, and others (could be completed by respondents). The respondents could choose more options.

The sample consisted of 130 students coming from 5 secondary schools in Slovakia. The students filled in the questionnaire electronically (via Google Forms) in their computer laboratories during lessons or at home. 6 questionnaires were excluded because the responses were not clear and could not be interpreted. The collected data were processed in MS Excel application and the results depicted in graphs.

\section{RESULTS AND DISCUSSIONS}

The first research question relates to the identification of heroes recognized by secondary school students. Fig. 1 presents the importance attached to individual categories with family member/relative $(39.02 \%)$ being the most recognized category followed by another publicly known person $(8.94 \%)$, singer $(8.13 \%)$, friend $(4.88 \%)$, and a sportsman/woman $(3.25 \%)$. If the categories of publicly known persons (sportsman/woman, singer, actor/actress, another publicly known person) were combined in one, such a category would account for $21.95 \%$.

The results suggest that the most influential impact on shaping adolescents ${ }^{6}$ behaviour via their heroes comes from family members and publicly known persons.

For adolescents their family is the primary social group where they identify with the behaviour of its members who they acknowledge and admire. Thus, the family members become their heroes who shape the adolescents' behaviour. The following category of publicly known persons may be attributed to the influence of the Internet and limitless access to the information of heterogeneous nature including a lot of news on well-known people. They become adolescents' heroes who they admire and directly or indirectly influence their behaviour. The number of respondents who claim that they do not recognize any hero is surprisingly high $(24.39 \%)$. The finding suggests that the respondents have not found any positive hero, but acknowledge heroes ad hoc and, thus, the influence on their behaviour is unclear.

To understand the impact of heroes on adolescents' behaviour it is more important to identify what values are represented by the heroes the adolescents recognize. There were several options the respondents could choose from. The percentage depicts the ratio of the responses in which the respondents decided for individual options.

The most acknowledged value recognized in heroes of all optional ones (Fig. 2) is wisdom and intelligence $(73.12 \%)$ 
followed by kindness $(60.22 \%)$, responsibility $(54.84 \%)$, friendliness and outgoingness (54.84), frankness (53.76\%), and honesty and fairness $(53.76 \%)$. The least admired value is wealth (money) (11.83\%), stubbornness (16.13\%), social influence $(27.96 \%)$, and beauty $(31.18 \%)$.

For the purpose of our research to combine the values with the identified heroes is crucial. Table 1 presents the four categories of heroes identified as the most important ones by the respondents (family member/relative, friend, sportsman/woman, singer).

In the category of family member/relative the most recognized values account for kindness $(79.17 \%)$, wisdom and intelligence $(77.08 \%)$, responsibility $(72.9 \%)$, the least acknowledged values are wealth (money) (2.08\%), social influence $(12.50 \%)$, stubbornness $(12.5 \%)$, creativity $(18.75 \%)$, success $(20.83 \%)$, and beauty $(22.92 \%)$. The results represent the most common family values (of course, they slightly vary in relation to the cultural context in which the family functions).

The category of friend is mostly characterized by wisdom and intelligence (100\%) and courage and fearlessness $(83.33 \%)$, the least exhibited values are social influence $(16.67 \%)$ and wealth (money) (16.67\%). Most of the identified values in this category are situated between the above extremes. This leads to the conclusion that referring to our friends we usually do not choose our friends based on the pre-set criteria. Then we tend to accept them as they are.

Even though the figures for other two categories (sportsman/woman and singer) are relatively under-represented, they suggest interesting findings. The category of sportsman/woman is characterized most by success $(100 \%)$, talent $(100 \%)$, honesty and fairness $(75 \%)$, and diligence $(75 \%)$. They are sportsmen/women who are usually portrayed as the bearers of these values. The least represented values include stubbornness $(0 \%)$, generosity $(25 \%)$, modesty $(25 \%)$, creativity $(25 \%)$, support of others $(25 \%)$, beauty $(25 \%)$, wealth (money) $25 \%$, kindness (25\%), wisdom and intelligence $(25 \%)$.

The most recognized values linked with the category of singer are talent $(100 \%)$, success $(90 \%)$, creativity $(80 \%)$, courage, and fearlessness $(80 \%)$, and beauty $(70 \%)$. These are the values that are generally attributed to the category. The least represented values are stubbornness $(0 \%)$, generosity $(10 \%)$, responsibility $(10 \%)$, honesty and fairness $(20 \%)$, modesty (20\%), support of others $(20 \%)$, kindness $(20 \%)$, and wealth (money) $(30 \%)$.

In comparison of individual categories of heroes and their attributed values the results account for extremes in some cases. While the category of sportsman/woman is characterized by the recognized values of honesty and fairness, in the category of singer these values are acknowledged little. Similarly, responsibility is highly recognized in the category of family member/relative, however, little valued in the category of singer. Talent is a good example of a value that is little recognized in the category of family member/relative, but highly acknowledged in the categories of sportsman/woman and singer.

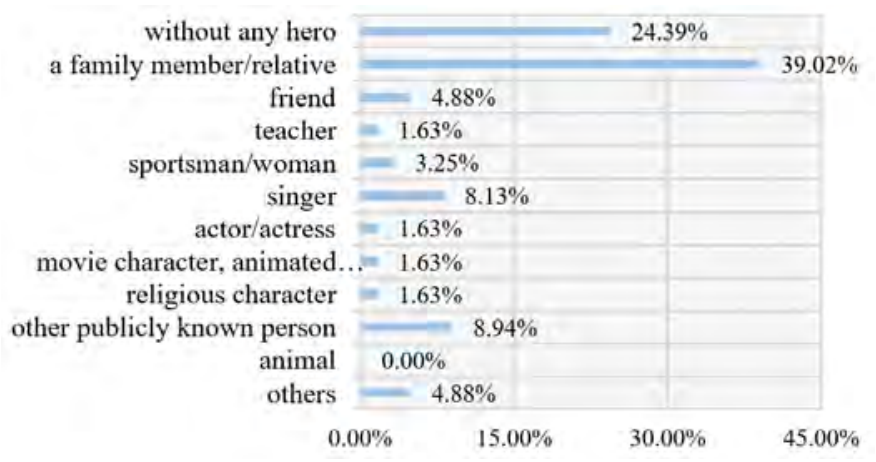

Fig. 1. The overview of hero categories recognized by respondents (Source: own research)

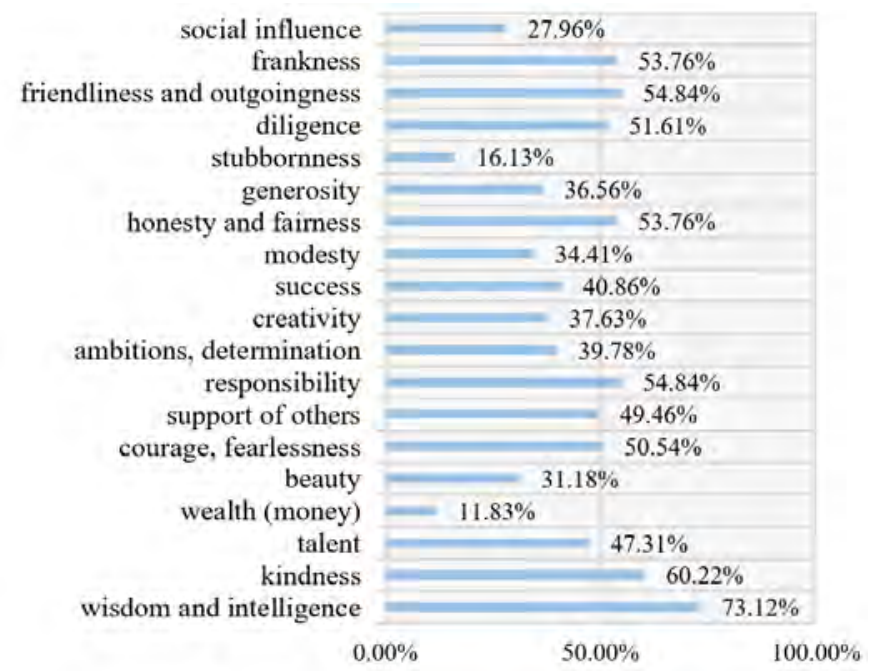

Fig. 2. The overview of values represented by the recognized heroes (Source: own research)

TABLE I. THE OVERVIEW OF VALUE - HERO COUPLING BY THE RESPONDENTS (SOURCE: OWN RESEARCH)

\begin{tabular}{|l|c|c|c|c|}
\hline \multicolumn{1}{|c|}{ Value/Hero } & $\begin{array}{c}\text { Family } \\
\text { member } \\
\text { /relative }\end{array}$ & Friend & $\begin{array}{c}\text { Sportsman } \\
\text { /woman }\end{array}$ & Singer \\
\hline social influence & $12.50 \%$ & $16.67 \%$ & $50.00 \%$ & $60.00 \%$ \\
\hline frankness & $58.33 \%$ & $33.33 \%$ & $50.00 \%$ & $30.00 \%$ \\
\hline friendliness and outgoingness & $58.33 \%$ & $66.67 \%$ & $50.00 \%$ & $60.00 \%$ \\
\hline diligence & $54.17 \%$ & $33.33 \%$ & $75.00 \%$ & $50.00 \%$ \\
\hline stubbornness & $12.50 \%$ & $33.33 \%$ & $0.00 \%$ & $0.00 \%$ \\
\hline generosity & $45.83 \%$ & $33.33 \%$ & $25.00 \%$ & $10.00 \%$ \\
\hline honesty and fairness & $58.33 \%$ & $66.67 \%$ & $75.00 \%$ & $20.00 \%$ \\
\hline modesty & $31.25 \%$ & $50.00 \%$ & $25.00 \%$ & $20.00 \%$ \\
\hline success & $20.83 \%$ & $50.00 \%$ & $100.00 \%$ & $90.00 \%$ \\
\hline creativity & $18.75 \%$ & $66.67 \%$ & $25.00 \%$ & $80.00 \%$ \\
\hline ambitions, determination & $27.08 \%$ & $50.00 \%$ & $75.00 \%$ & $40.00 \%$ \\
\hline responsibility & $72.92 \%$ & $66.67 \%$ & $50.00 \%$ & $10.00 \%$ \\
\hline support of others & $58.33 \%$ & $50.00 \%$ & $25.00 \%$ & $20.00 \%$ \\
\hline courage, fearlessness & $39.58 \%$ & $83.33 \%$ & $25.00 \%$ & $80.00 \%$ \\
\hline beauty & $22.92 \%$ & $33.33 \%$ & $25.00 \%$ & $70.00 \%$ \\
\hline wealth (money) & $2.08 \%$ & $16.67 \%$ & $25.00 \%$ & $30.00 \%$ \\
\hline talent & $25.00 \%$ & $66.67 \%$ & $100.00 \%$ & $100.00 \%$ \\
\hline kindness & $79.17 \%$ & $66.67 \%$ & $25.00 \%$ & $20.00 \%$ \\
\hline wisdom and intelligence & $77.08 \%$ & $100.00 \%$ & $25.00 \%$ & $40.00 \%$ \\
\hline & & & & \\
\hline
\end{tabular}




\section{CONCLUSION}

Currently, human resource officers apply various techniques to assess the candidate's personality fitting the vacancy and predict his/her future behaviour as an organization member; however, at the same time they look for the new methods or refine the used ones.

The identification of heroes recognized by the candidates looking for jobs, primarily in the case of adolescents entering the labour market for the first time, can be one of them. Obviously, it can be utilized in combination with other techniques because to identify the potential behaviour of employees must be based on holistic approach covering various perspectives.

Identification of adolescents' heroes can be used also in the period of preparation for their future professional career because they are malleable at that time and to advise them on behavioural models that could help them in the future can be prospective.

The findings show that the most represented category of heroes for secondary school students are those from their family followed by publicly known persons. The most acknowledged values recognized in heroes are wisdom and intelligence which indicates the interest in further education paths, followed by kindness, responsibility, friendliness and outgoingness, frankness, and honesty and fairness that might be assumed as a capacity for successful career in services.

The results, however, raises many questions. If family members represent the strong influence on prospective employees in the age category of $15-19$, how to deal with the ones coming from socially disadvantaged background with long history of unemployed family members? How to present them the heroes worth following from the perspective of their future career? Similar question occurs in relation to publicly known persons. It is quite common that their lifestyle does not represent the values the potential employers are looking for in their employees.

The findings are part of wider picture mapping the development of value systems identified via heroes in individuals; at the same time, the international comparison could disclose similar or different tendencies in value system development in young people in general. In addition, the impact of the heroes as models shaping the behaviour should be explored more closely. What can be done about the models leading to unwanted behaviour that are widely promoted? How to introduce the heroes as the models shaping behaviour in the expected direction? How to make them attractive? How to avoid manipulation in behaviour shaping? All the above questions need to be covered by future research.

\section{ACKNOWLEDGMENT}

The paper was prepared with the support of the project VEGA, no. $1 / 0393 / 16$.

\section{REFERENCES}

[1] European Commission, Europe 2020 strategy, Available at https:/ec.europa.eu/info/business-economy-euro/economic-and-fiscalpolicy-coordination/eu-economic-governance-monitoring-preventioncorrection/european-semester/framework/europe-2020-strategy_en

[2] Interviews with major employers in Slovakia.

[3] C.K. Sigelman and E.A. Rider, Life-Span Human Development, 8th ed., Stamford: Cengage Learning, 2015.

[4] E. Burman, Deconstructing Developmental Psychology, 3rd ed., Abingdon: Taylor \& Francis, 2016.

[5] J. Piaget, The theory of stages in cognitive development, Measurement and Piaget, New York: McGraw-Hill, 1971.

[6] L.S. Vygotsky, Mind in Society: The Development of Higher Psychological Processes, Cambridge: Harvard University Press, 1980.

[7] N. Kogan, L.J. Stricker, M. Lewis, and J. Brooks-Gunn, "Research on Developmental Psychology," Advancing Human Assessment, pp. 453486, October 2017.

[8] J.S. Eccles and R.W. Roeser, "School and Community Influences on Human Development," Developmental psychology: And advanced textbook, New Jersey: Lawrence Erlbaum Associates Publishers, 1999, pp. 566-638.

[9] S. Wood, Generation Z as Consumers: Trends and Innovation, Institute for EMERGING ISSUES: NC State University, 2013, pp.1-3.

[10] E. Maioli, "New Generations and Employment - An Exploratory Study about Tensions Between the Psycho-social Characteristics of the Generation $\mathrm{Z}$ and Expectations and Actions of Organizational Structures Related with Employment," Journal of Business, vol. 02(01), pp. 01-12, January 2017.

[11] S.B. Berkup, "Working With Generations X And Y in Generation Z Period: Management Of Different Generations In Business Life," Mediterranean Journal of Social Sciences, vol. 5(19), pp. 218-229, August 2014.

[12] W.J. Brown, M.D. Basil, and M.C. Bocarnea, "The Influence of Famous Athletes on Health Beliefs and Practices: Mark McGwire, Child Abuse Prevention, and Androstenedione," Journal of Health Communication, vol. 8(1), pp. 41-57, January 2003.

[13] F.I.C. da Silva, "Neymar, hero of children," Journal of Physical Education, pp. 28, June 2017.

[14] M.J. Melnick and S.J. Jackson, "Globalization American-Style and Reference Idol Selection," International Review for the Sociology of Sport, vol. 37(3-4), pp. 429-448, December 2002.

[15] J. Grác, J. Exemplifikácia: Vzory a modely v živote človeka,, Bratislava: Obzor, 1990.

[16] P. Bricheno and M.E. Thornton, "Role model, hero or champion? Children's views concerning role models," Educational Research, vol. 49(4), pp. 383-396, December 2007.

[17] L. Copuš, Vzory správania a hodnotová orientácia ako faktory budúcej úspešnosti zamestnancov, Ružomberok: Verbum, 2015. pp. 206-212.

[18] A. Bandura, Social Learning Theory, New Jersey: Prentice-Hall, 1977.

[19] N. Vrabec and D. Petranová, Nové vzory mládeže v kontexte mediálnej komunikácie, Prešov: Vydavatel'stvo Michala Vaška, 2013.

[20] H. Šajgalíková and L. Copuš, "Can Employers and Educational Institutions Learn More about Their Candidates Through Analysing Their Heroes?” IBIMA, 2017, pp. 3937-3944.

[21] L. Copuš, "Influence of Selected HR Competencies on the Performance of Organizations (Comparison of Indian and European Organizations)," 15th International Scientific Conference on Globalization and its SocioEconomic Consequences, 2015, pp. 94-101.

[22] L. Copuš, "Vzory úspešného správania budúcich zamestnancov," Rigorous Thesis, 2014.

[23] Z. Kotuliaková and I. Blahunková, "Overwiev of Selected Predictors of Unethical Behavior in the Workplace,” IBIMA, 2018, pp. 4243-4247.

[24] J. Horváthová-Suleimanová, M. Poláková, and E. Wojčák, Vlastnosti výberovej metódy assessment center, Bratislava: Aldo, 2013, pp. 50-56. 